similar to the Neocomian of Europe were actually contemporaneous with the latter formation, or merely homotaxical and representative of it, was not the question I proposed to deal with. The general sequence of animal life is admittedly the same in either case; and whether the Neocomian in Sonth America was or was not contemporaneons with the Neocomian in Europe, still it would have to be considered in comparative geology as Neocomian, at all events until some better nomenclature could be decided on. If Belemnites are not found above the Chalk, in Europe, it is probable they will not be found above the homotaxical representatives in South America of the Chalk.

I trust that this explanation will prove satisfactory to $\mathrm{Mr}$. Lankester and to those of your readers who may take an interest in the matter.

I am, Sir, your obedient servant,

Port of Spain, Trinidad, July 28th, 1863.

R. LeChMERE GUPPY.

\title{
Former Higher Temperature of the Earth v. Atmospheric Pressure.
}

Sin,-The Rev. James Brodie, at the late British Association Meeting, stated that if at any time the earth had been subjected to a great increase of temperature, it necessarily implied an immense increase of pressure in the atmosphere. A slight increase, he said, would double the atmospheric pressure. Can you, Sir, inform me the grounds of the assertion, and the reasons why the atmospheric pressure would be augmented by the increase of internal heat? Perhaps Mr. Brodie would condescend to enlighten myself and others of your readers who may be in the same ignorance as myself upon this very interesting subject, if you, Sir, cannot or decline to give us the explanation.

Yours respectfully,

Pulax.

Taunton, 4th September, 1863.

\section{BRITISH ASSOCIATION MEETING AT NEWCASTLE.}

The Section of Geology was under the Presidency of Mr. Warington W. Smyth.

President's Adpress. - If there is any one part of the British Islands where the very name of the place is naturally associated in our minds with a particular geological formation, it is the town of Newcastle as associated with coal; and, beyond a doubt, many of the present visitors to this cradle and centre of the coal trade will have made their journey hither with the expectation of not only hearing communications on various branches of geological science, but more especially of adding something to their knowledge of the carboniferous strata. We are to be favoured with several papers dealing with different portions of the subject, and it may be advisable that I should invite your attention to the state of our knowledge of the occurrence and history of the coal-measures generally, referring mainly to the phenomena which characterize that most valuable region in which we are assembled. I shall attempt, as it were, an overture giving a general ontline of the carboniferous plot, and introducing a few notes to illustrate those passages which are most likely, in our successive 